\title{
Antitussive Activity of the Ethanolic Extract of Paederia foetida (Rubiaceae family) in Non-Anaesthetized Cats
}

\author{
G. NOSÁLOVÁa , J. MOKRÝa, A. ATHER ${ }^{b}$, M. T. H. KHAN

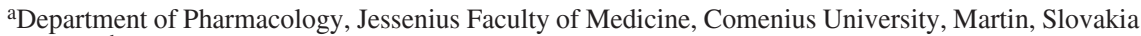 \\ bInternational Center for Chemical Sciences, H.E.J Research Institute of Chemistry, \\ University of Karachi, Karachi-75270, Pakistan \\ 'Pharmacology Research Laboratory, Faculty of Pharmaceutical Sciences, \\ University of Science and Technology Chittagong, Bangladesh \\ Received June 19, 2006 \\ Accepted October 20, 2006
}

\begin{abstract}
Nosálová G., J. Mokrý, A. Ather, M.T.H. Khan: Antitussive Activity of the Ethanolic Extract of Paederia foetida (Rubiaceae family) in Non-Anaesthetized Cats. Acta Vet. Brno 2007, 76: 27-33.

The aim of the present study was to examine the antitussive activity of the ethanolic extract of Paederiafoetida (P. foetida) in conscious cats by mechanical stimulation of laryngopharyngeal (LP) and tracheobronchial (TB) mucous areas of airways.

The results showed that the ethanolic extract of $P$. foetida at the oral dose of $200 \mathrm{mg} \cdot \mathrm{kg}^{-1} \mathrm{~b} . \mathrm{w}$. had a cough-suppressive effect. It caused a significant $(p<0.05)$ decrease of the number of cough efforts (NE) and frequency of cough $\left(\mathrm{NE} \cdot \mathrm{min}^{-1}\right)$ from both LP and TB areas. The intensity of a cough attack was significantly decreased only during inspirium $\left(\mathrm{IA}^{-}\right)$. Also a significant $(p<0.05)$ decrease was observed of the intensity of maximal effort in expirium (IME ${ }^{+}$) from $\mathrm{TB}$ area and inspirium ( $\mathrm{IME}^{-}$) from both LP and TB areas.

The antitussive activity of the ethanolic extract of $P$. foetida was lower than that of the classical narcotic antitussive drug - codeine, but similar to that of the non-narcotic antitussive agent dropropizine. The antitussive activity of the ethanolic extract of $P$. foetida may be connected with its previously demonstrated anti-inflammatory activity.
\end{abstract}

Cough, antitussive activity, Paederia foetida, codeine, dropropizine, conscious cats

Cough is a protective reflex mechanism removing foreign materials and secretions from the airways (foreign objects, mucus secreted during catarrhs of the respiratory system). However, in various situations it may be inappropriately stimulated, e.g. by inflammation in the respiratory tract, bronchial asthma or by neoplastic processes. In these cases cough is pathological and in some cases it is the reason for using cough-suppressing drugs. Antitussive agents are predominantly used for the suppression of dry and painful cough that disturbs the patient. It is notable that the use of this group of drugs is associated with the suppression of only one symptom, without influencing the underlying condition. Therefore, the administration of this kind of drugs should be prevented in cough associated with bronchiectasis or chronic bronchitis, because of possible harmful thickening of sputum and its retention. In the treatment of these patients agents are preferred with expectorant activity (secretolytics, secretomotorics and mucolytics), that suppress cough by other mechanisms (Rang et al. 1999; Ševecová and Čalkovská 2002).

Widely used antitussives in clinical conditions belong to the group of narcotic analgesics - so-called "codeine group". Their antitussive action is very strong at doses lower than those required for pain relief. Despite of their excellent efficacy they are associated with a relatively high rate of undesirable side effects, such as depression of the respiratory center, decreased mucus secretion in bronchioles, as well as inhibition of ciliary activity. Furthermore, their administration can lead to an increase of sputum viscosity, decrease of

Address for correspondence:

MUDr. Juraj Mokrý, PhD.

Department of Pharmacology

Jessenius Faculty of Medicine, Comenius University

Sklabinská 26

Phone: +421434132535

03753 Martin, Slovakia

Fax: +421434134807

E-mail: mokry@jfmed.uniba.sk

http://www.vfu.cz/acta-vet/actavet.htm 
expectoration, hypotension and constipation. Therefore it is important to explore other nonnarcotic substances preventing the pathological cough (Rang et al. 1999) .

Our interest was focused on the antitussive activity of ethanolic extract of Paederia foetida, locally known as "Gandhavadulia" (English name "skunkvine"). The decoction of the whole plant is traditionally used in Ayurveda medicine for the treatment of various diseases. Paederia foetida Fam. Rubiaceae (Bengali. Gandhavadulia, Eng. Skunkvine) is a perennial woody plant that is typically a climbing vinelike plant in the subtropical and tropical parts of Eastern and Southern Asia as well as in the southern parts of USA (Florida). The plant smells more or less like skunk. Skunkvine flowers are small pink or lilac; leaves are rounded-to-heart-shaped. The fruits are small, shiny brown orbs with two black seeds.

Although various characteristics of $P$. foetida were already reported such as antiinflammatory and hepatoprotective effects (De et al. 1993), there is no valid information about its antitussive activity. In our previous experiments we tested various plant extracts for their antitussive activity ( Althaea officinalis L., Rudbeckia fulgida, Mahonia aquifolium, Arctium lappa, Malva mauritiana and others), based especially on their polysaccharide structure (Kardošová et al. 1997, 2001, 2002, 2003; Nosálová et al. 1992, 1993, 1994, 2000; Franova et al. 1998) as well as that of typically found in Bangladesh (Emblica officinalis, Nosálová et al. 2003).

It is widely known that anti-inflammatory properties of various substances participate in their antitussive activity (Korpáš a Nosálová 1991). Due to the fact that in literature there are no references about the antitussive activity of $P$. foetida, we decided to fill in this information gap and assess whether this plant possesses also other effect(s), that could be potentially used in therapy of pathological forms of the cough.

The aim of this study was to evaluate the antitussive activity of ethanolic extract of $P$. foetida (EEPF) in conscious cats using the method of mechanically induced cough (Korpáš and Nosálová 1991) and to compare it with other known antitussives.

\section{Materials and Methods}

Extraction of plant materials

Five $\mathrm{kg}$ of dried whole plant (without roots, collected in spring months from Chittagong, Bangladesh) of $P$. foetida (Voucher sp. No. BC0107) was sopped in absolute ethanol for 15 days and then solvent was filtered off. Then the solvent was evaporated in vacuo at $40{ }^{\circ} \mathrm{C}$ and the residue was dried at $20^{\circ} \mathrm{C}$ under vacuum for 96 hours. The final yield was $16.78 \%$.

Doses and route of administration

The ethanol extract of $P$. foetida was given orally (p.o.) dissolved in water for injection (Biotika, Slovakia), and the dose of EEPF was $200 \mathrm{mg} \cdot \mathrm{kg}^{-1}$. This dose was selected according to our previous experiences from antitussive tests with other plant extracts (Nosálová et al. 1992, 2000, 2003; Kardošová et al. 2002).

Animals

We used nine healthy conscious cats of both sexes 1-3 years old, weighing 1500 - $3000 \mathrm{~g}$, to eliminate the possible effect of an anesthetic on cough reflex. The animals were bought from private breeders and located in faculty animal house for three weeks of quarantine. During the whole experiment, food and water were available ad libitum. All experiments were approved by local Ethical Committee at Jessenius Faculty of Medicine Comenius University in Martin and conducted in accordance with basic ethical norms and Helsinki Declaration of 1975, revised in 1983.

Experimental procedure

According to the procedure described in monograph by Korpáš and Nosálová (1991), the cough was evoked using a nylon fiber $0.35 \mathrm{~mm}$ in diameter by five consecutive mechanical irritations of laryngopharyngeal (LP) and tracheobronchial (TB) mucous areas of the airways in experimental animals. The changes of the lateral tracheal pressure were monitored and registered by surgically implanted chronic tracheal cannula. The single cough indicators were reviewed from registered pressure changes (Mingograph Elema device). We evaluated the number of cough efforts (NE), the intensity of the cough attack during expiration $\left(\mathrm{IA}^{+}\right)$and inspiration $\left(\mathrm{IA}^{-}\right)$, the cough frequency (NE.min ${ }^{-1}$ ) and the intensity of maximal cough efforts during expiration (IME ${ }^{+}$) and inspiration (IME-). Control (C) values for each cat were obtained by irritation before the application of the substance. The cough was evoked $0.5,1,2$ and $5 \mathrm{~h}$ after administration of the substance. The quantitative characteristic of the cough suppressive effect was expressed as antitussive activity (in per cent) (Korpáš and Nosálová 1991). 
Statistical analysis

Non-parametric Wilcoxon test was used for the statistical analysis of the results. The results are presented as mean \pm standard error of the mean (SEM). Significance of $p<0.05$ and $p<0.01$ is shown by one and two asterisks, respectively.

\section{Results}

By mechanical provocation of cough a significant reduction of the number of cough efforts (NE) in laryngopharyngeal (LP) area $30 \mathrm{~min}(p<0.05)$, and 1,2 and $5 \mathrm{~h}(p<0.01)$ after the administration of an oral dose of $200 \mathrm{mg} \cdot \mathrm{kg}^{-1}$ body weight (b.w.). Similarly, the significant reduction of NE in tracheobronchial (TB) area of the airways $30 \mathrm{~min}, 1 \mathrm{~h}(p<$ $0.01)$, and $2 \mathrm{~h}(p<0.05)$ after administration of this substance was observed. The reduction of NE from TB area 5 hours after administration was not significant (Fig. 1).

EEPF at the oral dose of $200 \mathrm{mg} \cdot \mathrm{kg}^{-1} \mathrm{~b} . \mathrm{w}$. significantly decreased the cough frequency from both irritated areas of the airways (Fig. 2).
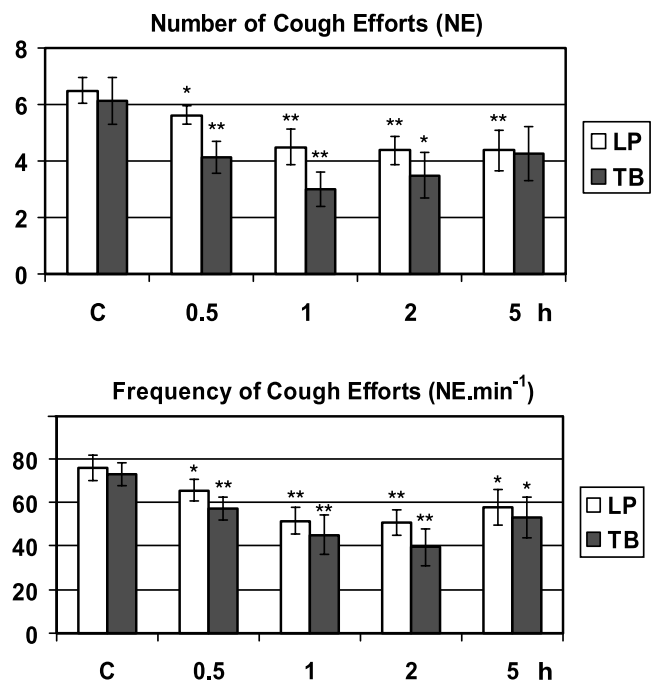

Intensity of Maximal Effort in Expirium (IME $\left.{ }^{+}\right)$

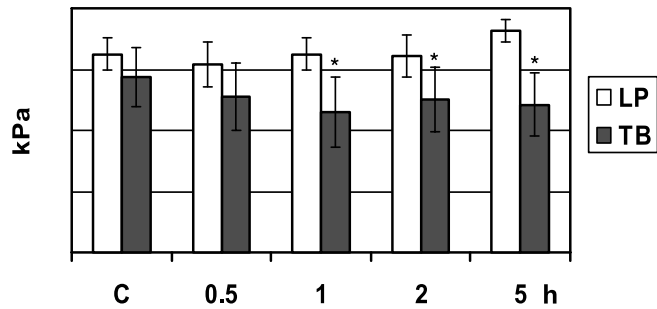

Fig. 1. Number of cough efforts (NE) recorded in Control (C marks values before application of tested substance) and 0.5, 1,2 and 5 hours after administration of $200 \mathrm{mg} \cdot \mathrm{kg}^{-1} \mathrm{~b}$.w. of ethanolic extract of $P$. foetida p.o. LP columns represent mean values of cough parameter from laryngopharyngeal area stimulation; TB columns represent mean values of cough parameter of tracheobronchial area stimulation. The range means the standard error of the mean ( \pm S.E.M.). Asterisks represent statistical significance according to paired Student's $t$-test $(* p<0.05, * * p<0.01)$.

Fig. 2. Frequency of cough efforts $\left(\mathrm{NE} \cdot \mathrm{min}^{-1}\right)$ after the administration of $200 \mathrm{mg} \cdot \mathrm{kg}^{-1} \mathrm{~b}$.w. of EEPF p.o. For explanation see Fig. 1.

Fig. 3. Intensity of maximal cough effort in exspirium $\left(\mathrm{IME}^{+}\right.$) after the administration of $200 \mathrm{mg} \cdot \mathrm{kg}^{-1} \mathrm{~b}$.w. of EEPF p.o. For explanation see Fig. 1.

The registered effects of EEPF on the intensity of maximal effort in expiration $\left(\mathrm{IME}^{+}\right.$, see Fig. 3) showed a significant decrease only in TB area. There was no reduction of $\mathrm{IME}^{+}$in LP area. The intensity of maximal effort in inspiration (IME-) showed a significant decrease in both irritated areas $30 \mathrm{~min}, 1$ and $5 \mathrm{~h}(p<0.01)$, as well as $2 \mathrm{~h}(p<0.05)$ after administration of $200 \mathrm{mg} \cdot \mathrm{kg}^{-1}$ b.w. of EEPF (Fig. 4).

There was no significant change observed in the intensity of cough attack during 
Intensity of Maximal Effort in Inspirium (IME')

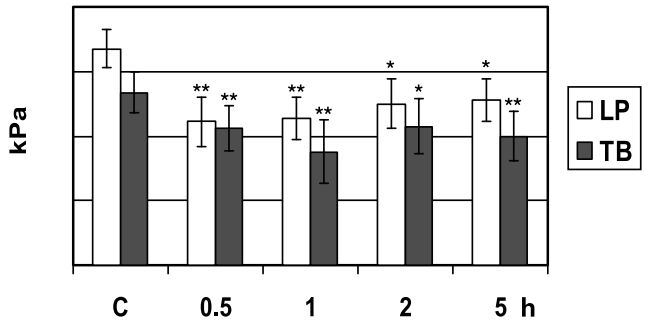

Intensity of Cough Attack in Expirium (IA $\left.{ }^{+}\right)$

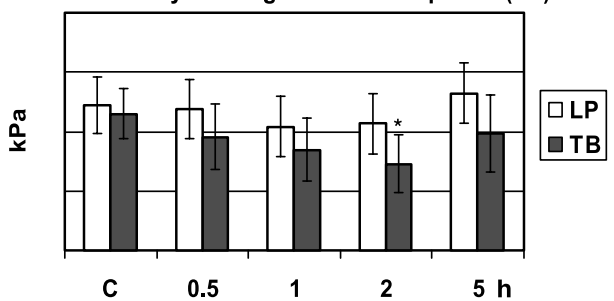

Intensity of Cough Attack in Inspirium (IA')
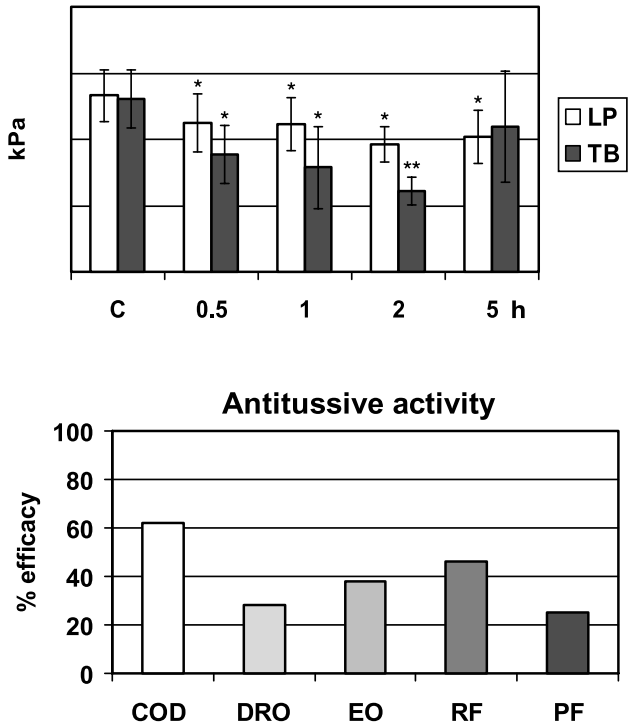

Fig. 4. Intensity of maximal cough effort in inspirium $\left(\mathrm{IME}^{-}\right)$after the administration of $200 \mathrm{mg} \cdot \mathrm{kg}^{-1} \mathrm{~b}$.w. of EEPF p.o. For explanation see Fig. 1.

Fig. 5. Intensity of cough attack during expirium $\left(\mathrm{IA}^{+}\right)$after the administration of $200 \mathrm{mg} \cdot \mathrm{kg}^{-1} \mathrm{~b}$.w. of EEPF p.o. For explanation see Fig. 1.

Fig. 6. Intensity of cough attack during inspirium (IA ${ }^{-}$) after the administration of $200 \mathrm{mg} \cdot \mathrm{kg}^{-1} \mathrm{~b}$.w. of EEPF orally. For explanation see Fig. 1.

Fig. 7. Comparison of antitussive activity of codeine in the dose of $10 \mathrm{mg} \cdot \mathrm{kg}^{-1} \mathrm{~b}$.w. (COD), dropropizine at the dose of $100 \mathrm{mg} \cdot \mathrm{kg}^{-1} \mathrm{~b}$.w. (DRO), E. officinalis at the dose of $200 \mathrm{mg} \cdot \mathrm{kg}^{-1} \mathrm{~b}$.w. (EO), Rudbeckia fulgida at the dose of $50 \mathrm{mg} \cdot \mathrm{kg}^{-1}$ b.w. (RF), and ethanolic extract of $P$. foetida at the dose of $200 \mathrm{mg} \cdot \mathrm{kg}^{-1}$ b.w. (PF) in conscious cats.

expiration $\left(\mathrm{IA}^{+}\right)$in LP area. The stimulation of TB area caused a decrease of $\mathrm{IA}^{+}$, but this was significant only 2 hours after administration of the substance (Fig. 5). The intensity of cough attack in inspiration (IA $\left.{ }^{-}\right)$was significantly decreased in both irritated areas: in LP area $30 \mathrm{~min}, 1,2$ and $5 \mathrm{~h}(p<0.05)$, and in TB area (Fig. 6) $30 \mathrm{~min}, 1 \mathrm{~h}(p<0.05)$ and $2 \mathrm{~h}(p<0,01)$ after administration of EEPF.

The antitussive activity of EEPF in the orally administered dose of $200 \mathrm{mg} \cdot \mathrm{kg}^{-1} \mathrm{~b}$.w. was $25.3 \%$. 


\section{Discussion}

Extracts of leaves and fruits of $P$. foetida have been used locally in Asia for antiinflammatory properties in the treatment of arthritis and for its antidiarrheal properties in the therapy of diarrhea or dysentery (Haider et al. 1991). Currently other effects of this plant are known, such as hepatoprotective effect (De et al. 1993), anti-tumour-promoting effect of paederosid present in P. foetida leaves (Kapadia et al. 1996), anthelmintic effect (Roychoudhury et al. 1970). Its anti-inflammatory activity was confirmed in several studies (De et al. 1993, 1994; Srivastava et al. 1973).

Haider et al. (1991) carried out a randomized, double blind, placebo-controlled clinical study to compare the efficacy of $P$. foetida in the therapy of shigellosis with that of ampicillin and placebo. Treatment with this indigenous plant did not show any clinical improvement or bacteriological cure as compared to ampicillin (Haider et al. 1991).

We suppose that some of the pharmacological properties of $P$. foetida mentioned above (especially the anti-inflammatory action) could take part in antitussive efficacy of the ethanolic extract of the $P$. foetida. We observed neither hypersecretion of mucus nor hypersalivation in all experimental cats during our experiments. After the administration of EEPF there was a temporary loss of appetite observed in all cats involved in experiments lasting for one to two days without significant weight loss. The p.o. administration of the dissolved EEPF was connected with aversion, probably due to bad taste or malodour.

In numerous studies for testing of antitussive activity of various plant extracts mice and rats were used (Mandal et al. 2000; Murugesan et al. 2000; Saha et al. 1997; Mukherjee et al. 1997) and cough reflex was provoked by sulfur dioxide or capsaicin (Pecova et al. 2003). In our experiments we chose mechanical stimulation of laryngopharyngeal (LP) and tracheobronchial (TB) mucous areas of airways in cats. We preferred mechanical stimulation to chemical or electrical stimulation because this impulse simulates the natural conditions of cough, induced by foreign solids or saliva. Moreover, it represents point stimulation; the intensity of irritation is constant and the possibility of receptor adaptation to this kind of irritation is unlikely (Nosálová et al. 1989). The mechanical stimulation of the airways represents objective methods for not only quantitative but also for qualitative evaluation of the antitussive activity. This fact is supported thereby the cats were not anaesthetized in order to eliminate the possible side effects of anesthetics to cough. According to Korpáš and Nosálová (1991), the cats are the most suitable animals for the cough modeling and the testing of various substances for their effects on the cough reflex.

We observed that EEPF in dose of $200 \mathrm{mg} \cdot \mathrm{kg}^{-1} \mathrm{~b}$.w. had quite a good potency to inhibit mechanically provoked cough. These effects were observed both in decreasing the number of efforts and intensity of attack, considered to be the most important factors in the predicting of the antitussive activity of any substance. The intensity of maximal effort was influenced significantly, too. This finding could represent a disadvantage from the point of view of expectoration, although this was not observed after administration of EEPF.

A comparison of the cough indicators from TB and LP regions revealed different abilities to influence the mechanisms regulating the quality and quantity of coughing. In all assessed parameters, the decrease observed after administration of EEPF was more significant in TB area.

The result also confirmed our earlier findings that compounds with dominant peripheral mechanisms reduce the frequency of coughing and have much less influence on its amplitude during expiration. The frequency of coughing depends probably on the condition of the cough receptors, whereas the amplitude is determined by the condition of the cough center (Korpáš and Nosálová 1991; Fraňová et al. 1995, 2000, 2001).

Comparison of the EEPF ability to suppress the cough to commonly used drugs in clinical 
practice as well as to other plant extracts is shown in Fig. 7. The excellent cough suppressing activity of centrally acting narcotic antitussive codeine $(62 \%)$ at a dose of $10 \mathrm{mg} \cdot \mathrm{kg}^{-1} \mathrm{~b}$.w. intraperitoneally (Strapková et al. 1984) is well known, but is accompanied by various side effects, which could limit its use (Rang et al. 1999). Codeine is used as a reference drug for antitussive activity tests. EEPF at the dose of $200 \mathrm{mg} \cdot \mathrm{kg}^{-1} \mathrm{~b}$.w. orally had similar antitussive activity as that of dropropizine $(28.3 \%)$ at the dose of $100 \mathrm{mgxkg}^{-1} \mathrm{~b} . \mathrm{w}$. intraperitoneally (Nosálová et al. 1985), widely used non-narcotic antitussive agent in clinical practice. The antitussive activity was lower than that of E. officinalis $(38.1 \%)$ at the same dose of $200 \mathrm{mg} \cdot \mathrm{kg}^{-1}$ b.w. orally (Nosálová et al. 2003) as well as that of orally administered polysaccharide complex isolated from leaves of Rudbecka fulgida (46\%) at the dose of $50 \mathrm{mg} \cdot \mathrm{kg}^{-1}$ b.w. (Nosálová et al. 2000).

In conclusion, our findings indicate that the antitussive activity of ethanolic extract of Paederia foetida in conscious cats is similar to that of commonly used non-narcotic antitussive dropropizine, suggesting its possible therapeutic use. However, further studies need to be done to evaluate its efficacy in clinical conditions.

\section{Antitusická aktivita etanolového extraktu Paederia foetida (fam. Rubiaceae) u neanestézovaných mačiek}

Cielom bolo stanovit antitusickú aktivitu etanolového výtažku Paederia foetida ( $P$. foetida) u neanestézovaných mačiek použitím mechanicky indukovaného kašla z laryngofaryngeálnej (LP) a tracheobronchiálnej (TB) oblasti sliznice dýchacích ciest.

Etanolový extrakt z P. foetida v perorálnej dávke $200 \mathrm{mg} \cdot \mathrm{kg}^{-1}$ telesnej hmotnosti spôsobil potlačenie mechanického kašla. Prejavilo sa to významným poklesom počtu nárazov kašla (NE) a frekvencie kašla (NE·min $\left.{ }^{-1}\right)$ z LP ako aj TB slizničnej oblasti dýchacích ciest. Intenzita kašlového ataku bola významne nižšia iba počas inspíria (IA-). Pozorovali sme aj signifikantný pokles sily maximálneho kašlového nárazu v exspíriu $\left(\mathrm{IME}^{+}\right)$z TB oblasti a v inspíriu (IME-) z LP ako aj TB oblasti dýchacích ciest.

Autori zistili významnú antitusickú aktivitu etanolového extraktu $P$. foetida, ktorá bola nižšia ako antitusické pôsobenie klasického narkotického antitusika - kodeínu, ale porovnatelná s účinkom nenakrotického antitusika dropropizínu.

Autori predpokladajú, že antitusická aktivita etanolového extraktu $P$. foetida je spojená s jej dokázaným protizápalovým pôsobením. Na potvrdenie tohto predpokladu sú však potrebné d’alšie sledovania.

\section{Acknowledgements}

This work was supported by VEGA grant No. 1/8155/01. The author M.T.H.K. would like to acknowledge the "South-South Fellowship" program of the Third World Academy of Sciences (TWAS), Italy, for his travel support to visit Pakistan.

\section{References}

DE S, RAVISHANKAR B, BHAVSAR GC 1993: Evaluation of Paederia foetida for hepatoprotective and antiinflammatory activities. Ind J Nat Prod 9: 7-11

DE S, RAVISHANKAR B, BHAVSAR GC 1994: Investigation of the anti-inflammatory effects of Paederia foetida. J Ethnopharmacol 43: 31-38

FRAŇOVÁ S, NOSÁLOVÁ G, CAPEK P, KARDOŠOVÁ A, STRAPKOVÁ A 1995: Antitussive active polysaccharides from flowers of Malva mauritiana L. Fol Med Martiniana 21-22: 109-116

FRAŇVÁ S, KARDOŠOVÁ A, KOŠŤÁLOVÁ D 1998: Herbal polysaccharides in the therapy of cough. Bratisl Lek Listy 99: 108-110

FRAŇVA S 2000: The relationship of ACE inhibitors to airways defense reflexes. JLFUK, Martin, p. 131

FRAŇOVÁ S 2001: The influence of inhaled furosemide on adverse effects of ACE-inhibitors in airways. Bratisl Lek Listy 102: 309-313

HAIDER R, KHAN AK, AZIZ KM, CHOWDHURY A, KABIR I 1991: Evaluation of indigenous plants in the treatment of acute shigellosis. Trop Geograph Med 43: 266-270 
KAPADIA GJ, SHARMA SC, TOKUDA H, NISHINO H, UEDA S 1996: Inhibitory effect of iridoids on EpsteinBarr virus activation by a short-term in vitro assay for anti-tumor promoters. Cancer Lett 102: 223-226

KARDOŠOVÁ A, KOŠT̃́LOVÁ D, CAPEK P, PÄTOPRSTÝ V, FRAŇOVÁ S 1997: Water-extractable polysaccharide complex of Rudbeckia fulgida, var. Sullivantii (Boyton et Beadle) possesses antitussive activity. Chem Pap 51: 52-59

KARDOŠOVÁ A, MALOVIKOVÁ A, PÄTOPRSTÝ V, NOSÁLOVÁ G, MATÁKOVÁ T 2002: Structural characterization and antitussive activity of glucuronoxylan from Mahonia aquifolium (pursh) Nutt Carbohydr Polym 47: 24-33

KARDOŠOVÁ A, EBRINGEROVÁ A, ALFÖLDI J, NOSÁLOVÁ G, FRAŇOVÁ S, HŘíBALOVÁ V 2003: A biologically active fructan from the roots of Arctium lappa L., var. Herkules. Int J Biol Macromol 33: 135140

KORPÁS̆ J, NOSÁLOVÁ G 1991: Pharmacotherapy of cough. Martin: Osveta, p. 335

MANDAL SC, KUMAR CKA, MOHANA LAKSHMI S, SINHA S, MURUGESAN T, SAHA BP, PAL M 2000 : Antitussive effect of Asparagus racemosus root against sulfur dioxide-induced cough in mice. Fitoterapia 71: 686-689

MUKHERJEE PK, SAHA K, BHATTACHARYA S, GIRI SN, PAL M, SAHA BP 1997: Studies on antitussive activity of Drymaria cordata Willd. (Caryophyllaceae). J Ethnopharmacol 56: 77-80

MURUGESAN T, GHOSH L, MUKHERJEE PK, PAL M, SAHA BP 2000: Evaluation of antitussive potential of Jussiaea suffruticosa Linn. extract in albino mice. Phytother Res 14: 541-542

NOSÁLOVÁ G, STRAPKOVÁ A, KORPÁŠ J 1985: A study of antitussic activities of dropropisine and butamirat citrate. Respirat Pharmacol, Bratislava, INCHEBA: 85-92

NOSÁLOVÁ G, STRAPKOVÁ A, KORPÁŠ J 1989: A kohogés gyógyszeres befolyásolása (Pharmacological influence on cough). Med Thorac 42: 61-73

NOSÁLOVÁ G, STRAPKOVÁ A, KARDOŠOVÁ A, CAPEK P, ZATHURECKÝ L, BUKOVSKÁ E 1992: Antitussive Wirkung des Extraktes und der Polysaccharide aus der Eibisch (Althaea officinalis L., var. Robusta). Pharmazie 47: 224-226

NOSÁLOVÁ G, STRAPKOVÁ A, KARDOŠOVÁ A, CAPEK P 1993: Antitussive activity of a rhamnogalacturonan isolated from the roots of Althaea officinalis L., var. Robusta. J Carbohydr Chem 12: 589-596

NOSÁLOVÁ G, CAPEK P, KARDOŠOVÁ A, STRAPKOVÁ A 1994: Changes in cough induced by administration of polysaccharides from flowers of Malva mauritiana L. Pharm Pharmacol Lett 3: 245-248

NOSÁLOVÁ G, KARDOŠOVÁ A, FRAŇOVÁ S 2000: Antitussive activity of a glucuronoxylan from Rudbeckia fulgida compared to the potency of two polysaccharide complexes from the same herb. Pharmazie 55: 65-68

NOSÁLOVÁ G, MOKRÝ J, KHAN MTH 2003: Antitussive activity of the fruit extract of Emblica officinalis Gaertn. (Euphorbiaceae). Phytomedicine 10: 583-589

PECOVA R, FRLICKOVA Z, PEC J, TATAR M 2003: Cough sensitivity in atopic dermatitis. Pulm Pharmacol Ther 16: 203-206

RANG HP, DALE MM, RITTER JM 1999: Pharmacology $4^{\text {th }}$ ed. Edinburgh, London, New York, Philadelphia, Sydney, Toronto: Churchill Livingstone, p. 830

ROYCHOUDHURY GK, CHAKRABARTY AK, DUTTA B 1970: A preliminary observation on the effects of Paederia foetida on gastro- intestinal helminthes in bovines. Indian Vet J 47: 767-769

SAHA K, MUKHERJEE PK, MURUGESAN T, SAHA BP, PAL M 1997: Studies on in vivo antitussive activity of Leucas lavandulaefolia using a cough model induced by sulfur dioxide gas in mice. J Ethnopharmacol 57: 89-92

SRIVASTAVA MC, TEWARI JP, KANT V 1973: Anti-inflammatory activity of an indigenous plant - Paederia foetida (Gandhali). Indian J Med Sci 27: 231-234

STRAPKOVÁ A, NOSÁLOVÁ G, KORPÁŠ J 1984: New aspects of the antitussive effects of codeine. Bratisl Lek Listy 81: 182-187

ŠEVECOVÁ D, ČALKOVSKÁ A 2002: Niektoré neštandardné možnosti liečby syndrómu aspirácie mekónia. Čes-Slov Pediat 57: 187-191 
